IJ§ER

ISSN: 2149-5939
International Journal of Social Sciences and Education Research

Online, http://dergipark.gov.tr/ijsser

\title{
Education and knowledge are fundamental to social justice and economic growth
}

\author{
Aïcha El Alaoui ${ }^{1}$
}

Received date: 29 / 04 / 2019

Accepted date: 30 / 06 / 2019

\begin{abstract}
This paper tries to explain that both knowledge and education are the way to increase economic growth and social justice. We have used the panel data to check the relationships between four indicators: knowledge, education, economic growth, and social justice. These data are from the Social Progress Imperative Organization (2018). We have used the statistic method (mode, quartile, and decile) to analyze our data though they are not enough. So, we found that 54 countries in the world have the lowest revenue between $\$ 600$ and $\$ 9,300$. They set forth almost $43 \%$ among 126 countries. In this modal class, about 6\% have the lowest rate SPI (Social Progress Index) in the world - it is between 20 and 40-, and more than 94\% have a rate SPI between 40 and 80. The results of the OLS regressions show that the improvement of social progress can increase GDP per capita to seven times what it was. On the other hand, both improvements in knowledge and education can increase GDP per capita to thirteen times what it was.
\end{abstract}

Keywords: Knowledge, Education, Economic Growth, Social Justice

\section{Introduction}

Education is an investment that increases the stock of skills and knowledge of the population which affects positive economic growth. The reason is quite simple, economic growth does not only depend on material capital; but it depends on intangible/immaterial capital too, where education plays a crucial role in its formation and accumulation.

Yet, education doesn't have only this positive impact; its impact spreads to social indicators. Tilak Jandhyala B.G. (1989) confirmed that "...returns to education being fairly compatible with, if not more than those to investment in physical capital," (Tilak Jandhyala, 1989, p.60). So, education as well as its positive role in economic growth, plays an important role, namely to reduce poverty and to improve income distribution.

Education [...] is a "great transformer." It influences the "basic real constraints in development that are related to social and economic dimensions and are structural in nature," (Tilak Jandhyala, 1989, p.61). The author found that education contributes positively and significantly to a reduction in income inequality and the proportion of the population below the poverty level declines, especially in a rural area when the literacy levels of the population, and the enrollment in education increase.

\footnotetext{
${ }^{1}$ Associate Professor, Poly-disciplinary Faculty. University of Sultan Moulay Slimane, BeniMellal, Morocco. President of "Dihia Centre for Human Rights, Democracy and Development" Chief of research group of "Solidary economic and Social Justice", and Member of research group of "International Migration and Territorial development" Phone Number: +212 663506211, Email: aicha_elalaoui@yahoo.fr
} 
El Alaoui, A. (2019). Education and knowledge are fundamental to social justice and economic growth. International Journal of Social Sciences and Education Research, 5(3), 279-293.

Education in better conditions is an "important catalyst for social and economic development," (UNESCO, 2012, p.3). It is a master-key to create optimal conditions for achieving development goals as signaled by UN because there is "an interconnectedness of all development goals with key inter-linkages between education, health, poverty reduction, and gender equality, where improvement in one area has a positive effect on the others," (UNESCO, 2012, p.3).

On the whole, there is various research in economic development that documented the positive impact of education on health, poverty reduction, gender equality, elimination of hunger, and so on. In its report, UNESCO (2014) confirmed that "education reduces poverty, boosts job opportunities and fosters economic prosperity. It also increases people's chances of leading a healthy life, deepens the foundations of democracy, and changes attitudes to protect the environment and empower women", (UNESCO, 2014, p.13).

In my previous studies, we found that women's education (especially tertiary education) is the foremost way to improve economic development accompanied by the good quality of institutional capital and by eliminating all forms of gender discrimination, (El Alaoui, 2016). This study tries to explain that achieving education and knowledge for all as the great way to increase domestic and national resources, to improve people's chances of a healthier life, to promote democratic societies, to motivate people to participate in politics and to help people understand the causes and effects of climate change. In another meaning, we try to explain that education and knowledge can promote both a healthier individual life and a healthier collective life, explaining that these factors have a vital role to promote equality, social justice, and economic development.

Establishing a free and fair society is central to contemporary political strategy. For that, understanding the role of education and knowledge is crucial to highlight its many policy consequences. First, it is important to focus on the causes of poverty as well as its symptoms; education and knowledge are the best way to reduce it in the long-term. Secondly, it is important to give women and girls the 'weapon' or the real defense to protect them of gender discrimination, physical and psychological violence; education and knowledge are also the best way to stop it forever. Finally, it is important to focus on the causes of religious violence/terrorism; education and knowledge are also an 'amazing' shine to have tolerance and peace, and an approach to accept our differences.

This paper is organized as follows. The second section tries to explain the meaning of social justice and to analyze the relationship between social justice and economic growth. The third section attempts to offer what why education and knowledge can be an important instrument to improve social justice and economic growth. The last section presents the concluding remarks.

\section{What do we mean by social justice?}

Why there are society's inequalities? Why there are various views of social justice? Is there a unique system to make society fairer? What is fair and what is unfair? What do we mean by social justice?

Since the industrial revolution, economic inequalities and social instability have been raised because of the nature of the capitalist system which has taken the world of civil conflict, war, unfair, unjust, pollution, natural destruction, and famine. Numerous studies declared, namely that (i) fewer people have owned more wealth than the rest of the people; (ii) more people live in 
El Alaoui, A. (2019). Education and knowledge are fundamental to social justice and economic growth. International Journal of Social Sciences and Education Research, 5(3), 279-293.

poverty and hunger; (iii) many children dead because they were private to good nutrition and care, and (iv) the incomes of the poorest of people increased miserably than that the richest of people.

All countries (namely developing countries) started the $21^{\text {st }}$ century with hard negative outcomes. Their people live in unfair, inequity and discrimination. In reality, a few people control the world. They dominate the resources, from oil to minerals to fish to vegetables and fruits, to trees and so on, and control the destiny of all people in the world withheld political rights from all populations (especially from women and minority ethnic) and ignored social justice, economic fairness and human rights, (Reisch, 2002). Besides, the huge exploitation of these resources was causing pollution, environmental destruction and diseases (e.g., cancer, stress, obesity and selfdestruction).

After the Arab revolution started in Tunisia (2011), social mobilizations, protests, and occupations are multiplying. They claim, namely, social justice, fair distribution of resources, cultural justice, and political democracy. These are the claims of all modern societies developed or developing, which try to guarantee democracy to their citizens. Democracy indicates not only a political regime but a Welfare State as defined by Alexis de Tocqueville (1805-1859) ${ }^{1}$. The concept of social justice is referred here to behaviors of the state or society. Questions are to describe and to check what are the criteria for the distribution and redistribution of wealth should be used by the State? These criteria must be starting assumption of equal dignity: all citizens should have the same opportunities to lead a self-determined life and to participate in politics (Alexis de Tocqueville, 1831). In other words, it is time to set up a new economic system associated with social justice where the State supervises and controls the distribution/redistribution of income, wealth and resources. So, the challenge is to inaugurate a positive alternative, able to chuck insecurity and fear and to assure fairness to all people.

Many academic papers/books that attempt to define the concept of justice. It is impossible to present all of them; we can mention some of them. We start by philosophers of the ancient Greek/Greece who inaugurated the first school of justice, such as Plato and Aristotle.

Plato said that "justice is consisted of what is lawful and fair, with fairness involving equitable distribution and the correction of what is inequitable," (cited in Internet Encyclopedia of Philosophy, 2017). His idea was that "each person received the goods they deserved based on their prescribed position in the social order" (cited by Srivastava, A.K., and Sharma, S., 2017, p.84). According to Plato, the concepts of individual and social justice are related by asserting that justice was derived "from the harmony between reason, spirit, and appetite present in all persons." For Aristotle, he said that justice was a principle that ensured social order by regulating the allocation and distribution of benefits; corresponding that "if the people involved are not equal, they will not [justly] receive equal shares; indeed, whenever equals receive unequal shares or unequal equal shares, ... that is the source of quarrels and accusations," (cited by Reisch, 2002, p.344). Aristotle's views, equality, and justice applied only to people who occupied the same stratum of the hierarchical social order," (cited by Srivastava, A.K., and Sharma, S., 2017, p.84). Plato and Aristotle defined social justice as unequal distribution of resources which is based on an unequal in social hierarchy or position in society.

1 For more explication see a "Special Introduction” By Hon. John T. Morgan, https://www.marxists.org/ reference/archive/de-tocqueville/democracy-america/introduction.htm

2 Source: http://www.iep.utm.edu/justwest/, date of consultation 07/12/2017. 
El Alaoui, A. (2019). Education and knowledge are fundamental to social justice and economic growth. International Journal of Social Sciences and Education Research, 5(3), 279-293.

The concept of justice was developed in several civilizations and in different religions, especially in Judaism, Christianity, Islam, and Buddhism. The common point among these religious is that they have given great importance to faith, hope, equality in treatment, and charity (as a way of distribution). However, they defend the social hierarchy which was explained by the individual's merit which is related to their social status or position in society. However, the concept of social justice was first used in 1840 by a Sicilian priest, Zajda (2010). During the enlightenment, the philosophers influenced by the scientific revolution discussed the idea of justice on the outside religious truths.

Certainly, there are many definitions of social justice because this notion is linked especially to political institutions, economic system, and sociocultural context. In fact, the economists focused on it because many studies were found that economic growth is explained by other variables than that economics, such as human rights, democratic institutions, gender equality, poverty, good health, low rate of mortality, and so on. Most of these factors have a strong relationship between economic development and social development, although, sometimes, we cannot make or find the clear impact or the difference between them. For that, the economists give attention to questions of justice.

To define social justice, we can refer also to Mill, J.S., (1971), Rawls (1971), Nozick (1974), Hayek (1976), Mead (1986), Sen (1990, 2003), Sunstein (1997), Reisch, M. (2002), and Moyes, P., (2011). Jermy Bentham (1748-1832) is considered as the first founder of the utilitarianism which was developed during $19^{\text {th }}$ and $20^{\text {th }}$ centuries. But, the most important views of utilitarianism, we can allude to Mill (1971). He said that utilitarianism was a standard of morality which used happiness of the greater number of people in a society. He meant the well-being of many people. In fact, he clarified that the distribution should be for almost all people calculating the greatest net balance of satisfaction for society. By the way, many discussions started to analyze the relationship between utilitarianism and welfare, (Moyes, 2011).

In his book "A Theory of Justice" (1971), John Rawls argues that "as a philosophical guide utilitarianism creates no imperative of social justice, since it can be used to rationalize a concentration of goods benefiting the privileged classes of society," (mentioned in Reisch, M., 2002, p. 346). Rawls defended that "each person possesses an inviolability founded on justice denies that the loss of freedom for some is made right by a greater good shared by others," (Rawls, 1971:3).

In this paper, it is not possible to discuss all theories of justice or social justice. But we can use Kelso and Adler's definition (1958) referring to economic justice who confirmed that social justice is based on three major principles: the principle of distribution, the principle of participation, and the principle of limitation. They highlighted that "justice, in its most general formulation, imposes the following moral duties or precepts upon men who are associated for the purposes of a common life: (i) to act for the common good of all, not each for his own private interest exclusively; (ii) to avoid injuring one another; (iii) to render to each man what is rightfully his due; and (iv) to deal fairly with one another in the exchange of goods and in the distribution of wealth, position, status, rewards, and punishments," (Kelso and Adler, 1958, p.79).

\section{Is there a relationship between social justice and economic growth?}

With a greater understanding of the views on what principles are forming the concept of social justice, we can perceive that it depends on the political ideology namely Liberalism, Socialism or Marxism. Thus, if we consider that the concept of justice is based on equal rights, equal freedom, 
El Alaoui, A. (2019). Education and knowledge are fundamental to social justice and economic growth. International Journal of Social Sciences and Education Research, 5(3), 279-293.

and equal life chances, regardless of origin or gender or religion, where State plays a major-key in insuring them, we can easily and quickly assure at the same time economic and social development and environmental protection. Consequently, we can find the optimum balance that guarantees both individual and societal/community well-being. In this view, social justice will be included in all levels of the economic system, on the horizontal and vertical processes. On the other hand, social justice necessitates individual responsibility and societal/ community/ shared responsibility and must satisfy their necessities or needs, too.

In any way, the gross domestic product (GDP) cannot measure the material and immaterial satisfaction and happiness of each person in society; it is useful to use other variables to assess social development, economic development, and environmental preservation/protection. During the last decades, many indicators were developed to try to measure, namely, social development. In this study, we use the Social Progress Index (SPI).

The SPI is "an aggregate index of social and environmental indicators that capture three dimensions of social progress: Basic Human Needs, Foundations of Well-being, and Opportunity" (www.socialprogressindex.com). The SPI rates 128 countries for 50 indicators which were rearranged in three dimensions aforesaid. In this paper, we use SPI for two reasons. First, this index includes the main dimensions that are linked to an individual's daily life. Secondly, it is not, to my knowledge, other works have used this index.

According to the SPI 2017, Morocco ranked 78 among 128 countries with the score of SPI is 65.25, followed such as by Indonesia, Botswana, Nicaragua, Egypt, and China. Although Tunisia and Algeria ranked 51 and 75, respectively, which they have the 'same' economic and social situation as like Morocco. In order of SPI, the top ten countries are Denmark, Finland, Iceland, Norway, Switzerland, Canada, the Netherlands, Sweden, Australia and New Zealand, Table A.1 in the Appendices.

Figure 1 shows the relationship between the average GDP per capita and the average SPI in 126 countries during 2014-2017. We can remark that this relationship is positive, strong and not linear.

Figure 1. Average GDP per capita, PPP (constant 2011 international \$) Vs. average SPI, during 2014-2017

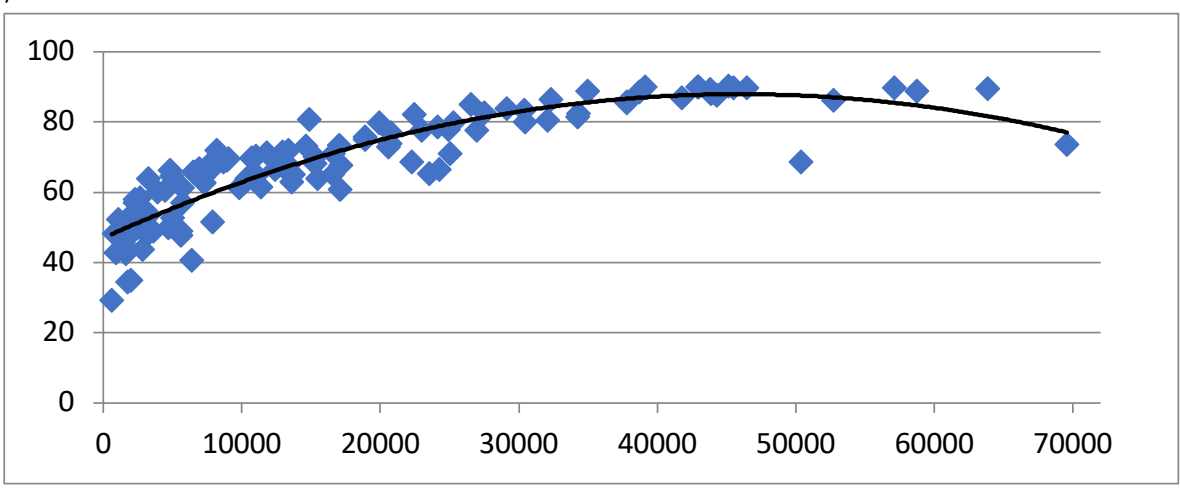

Source: Elaborated according to data of the social progress imperative organization, 2018

We remark that (i) a country with a similar average GDP per capita has achieved widely divergent levels of social progress, such as Albania, Egypt, Indonesia, Malawi, Madagascar, Togo, and Sri-Lanka; (ii) a country with a high average GDP per capita has achieved middle social progress, such as Saudi Arabic and Kuwait; (iii) a country with low average GDP per 
El Alaoui, A. (2019). Education and knowledge are fundamental to social justice and economic growth. International Journal of Social Sciences and Education Research, 5(3), 279-293.

capita has achieved high levels of social progress, such as Mauritius, Argentina, Croatia, Latvia, Hungary, Greece, Uruguay, Poland, Chile and Portugal, and (iv) Although Kuwait ranked first in average GDP per capita, but it ranked fortieth $\left(40^{\text {th }}\right)$ in average SPI. However, Denmark ranked eighth $\left(8^{\text {th }}\right)$ in average GDP per capita and it ranked first on the average SPI.

\section{How can we explain those situations of countries?}

If the relationship between GDP per capita and SPI exists, how can we explain it?

To explain the relationship between the GDP per capita and social progress, we emanate as follows: first, we classify 126 countries by income and social progress using Sturge's rule; then we apply the ordinary least-squares (OLS) regressions.

Classifying data via Sturge's rule, the number of tha class is eight (8) using the following formula:

Number of class $(\mathrm{k})=1+\left(3.322 \log _{10}(\mathrm{n})\right)$

Where, $n$ is the number of observations: $n=126$

$\mathrm{Y}$ is the GDP per capita

Minimum of GDP per capita: $\operatorname{Min}(\mathrm{Y})=\$ 600$

Maximum of GDP per capita: $\operatorname{Max}(Y)=\$ 70,200$

We choose $20 \%$ as the amplitude of class to classify SPI, and obviously the minimum and maximum are $0 \%$ and $100 \%$, respectively. Table A.2 in the Appendices shows the results of GDP per capita and SPI.

The results of these groupings display a positive and strong relationship between economic growth and social progress as in panel data. The following figures show the relationships between the average GDP per capita and the average social progress for each class/group. We note that the last three groups are represented in the same figure because the data are not sufficient. Consequently, we have just six (6) groups for the graphic presentation.

The modal class is the first class [600;9300[, meaning that 54 countries in the world have the lowest revenue. They almost present $43 \%$ among 126 countries. In this modal class, about $6 \%$ have the lowest rate SPI in the world -it is between 20 and 40 - and more than $94 \%$ have a rate SPI between 40 and 80 .

Measuring and quantifying the impact of social justice on the GDP per capita, we use the ordinary least-squares (OLS) regressions. The empirical specification for the cross-sectional analysis is as follows:

$$
\mathrm{Y}_{\mathrm{i}}=\mathrm{a}_{\mathrm{i}}+\mathrm{b}_{\mathrm{i}} \mathrm{SJ}_{\mathrm{i}}+\mathrm{e}_{\mathrm{i}} \text { Eq.1 }
$$

Where, $\mathrm{Y}_{\mathrm{i}}$ is the logarithm of the average GDP per capita during 2014-2017; $\mathrm{SJ}_{\mathrm{i}}$ is the average of the social justice index (SPI) during 2014-2017; $a_{i}$ and $e_{i}$ are the intercept and the error term respectively, and $b_{i}$ measures the impact of the social justice index on the logarithm of the GDP per capita.

The equation Eq1 is used in three manners. First, it applied for $50 \%$ of the data used, meaning 63 countries are integrated. Secondly, it applied for $80 \%$ of the data used, meaning 101 countries are integrated. Thirdly, it is used for all data (126 countries). The reason behind this is to drop in 
El Alaoui, A. (2019). Education and knowledge are fundamental to social justice and economic growth. International Journal of Social Sciences and Education Research, 5(3), 279-293.

the first case and the second case, the extreme incomes (GDP per capita), the countries which have higher-income or lower-income, and then we can verify and compare the results for all cases.

Figure 2. Relationships between the average GDP per capita and average SPI for each class of countries, 2014-2017

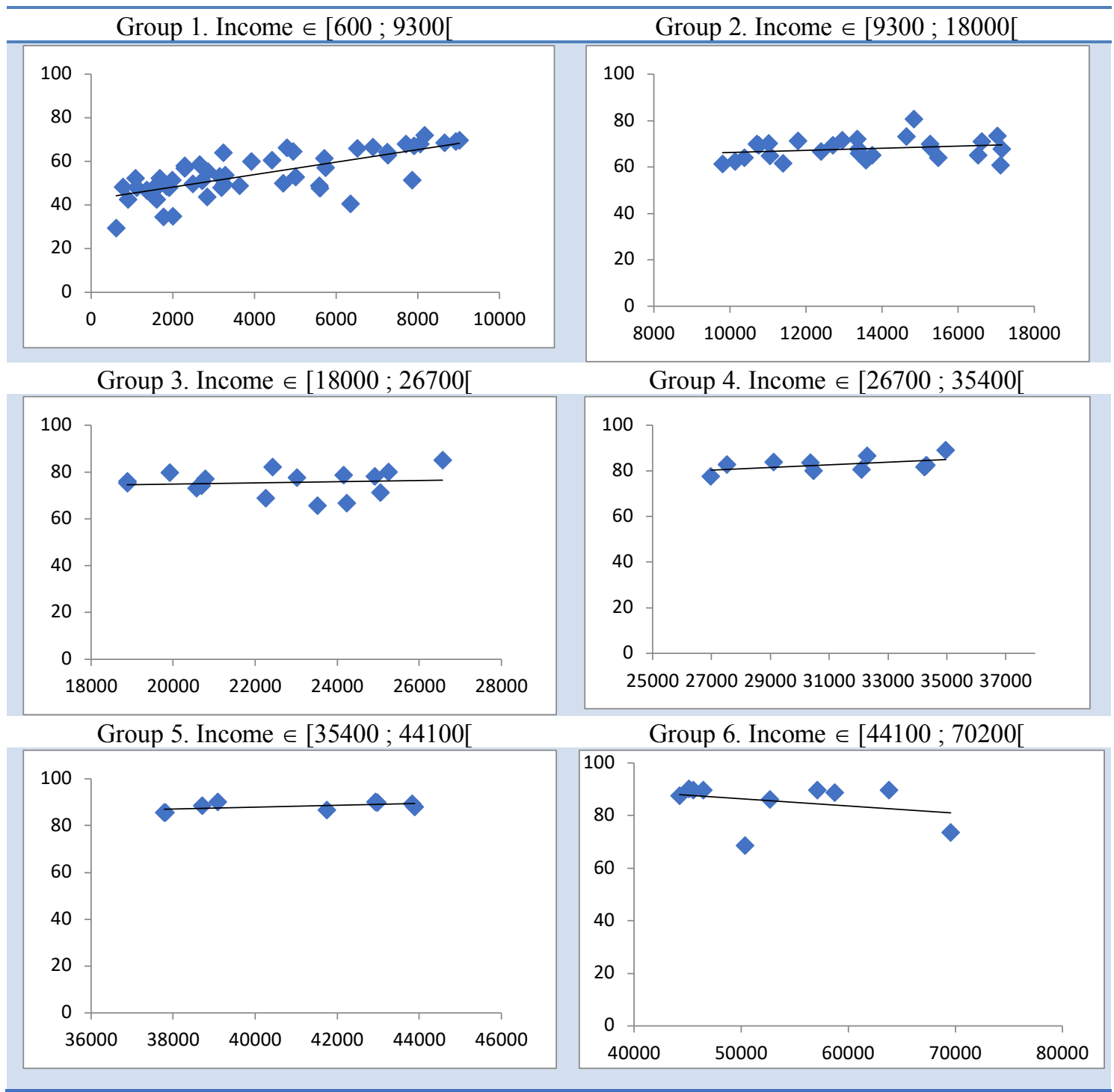

Source: Our elaboration

Using the quartile method, the data used are divided into four equal slices/parts. The first part includes the lowest $25 \%$ of the observation (income/GDP per capita). The second part contains the next lowest $25 \%$ of the observation (up to the median). The third part holds the second-highest $25 \%$ of the observation (above the median). The last part presents the highest $25 \%$ of observation. In this study, we exclude the first part (the lowest $25 \%$ ) and the last part (the highest $25 \%$ ). Therefore, we apply the OLS regressions only about $50 \%$ of the numbers (income) stayed/stilled, named QuartData. The results of this regression show empirically that social justice positively impacts GDP per capita as follows:

$\mathrm{Y} 1_{\mathrm{i}}=\quad 6.483035+0.042581 \mathrm{SJ} 1_{\mathrm{i}}$


El Alaoui, A. (2019). Education and knowledge are fundamental to social justice and economic growth. International Journal of Social Sciences and Education Research, 5(3), 279-293.

\begin{tabular}{lll}
$($ Std. Error $)$ & $(0.396700)$ & $(0.005897)$ \\
{$[\mathrm{t}-$ Statistic $]$} & {$[16.34242]$} & {$[7.220853]$} \\
$\mathrm{R}^{2}$ & 0.460848 & \\
Observations & 63 & \\
\hline \multicolumn{2}{l}{ Source: our calculation }
\end{tabular}

Social justice's coefficient is positive and significant at the $1 \%$ level, but with R2 relatively feeble $46 \%$. This coefficient shows that about $4.4 \%$ increase in GDP per capita for only one point in the social justice index. Thus, $4.4 \%$ of the variation in income is explained by social justice.

The decile is like quartile, but while quartile sort data into four quarters, decile sort data into ten equal parts. Each part presents $10 \%$ of the observation. Using the OLS regression for $80 \%$ of the observation excluding the first part (the lowest 10\%) and the last part (the highest $10 \%$ ), named DecilData. The results display empirically that social justice positively impacts GDP per capita as follows:

\begin{tabular}{lll}
\hline $\mathrm{Y} 2{ }_{\mathrm{i}}=$ & 5.020162 & $+0.063133 \mathrm{SJ} 2_{\mathrm{i}}$ \\
$($ Std. Error $)$ & $(0.229865)$ & $(0.003376)$ \\
{$[\mathrm{t}-$ Statistic $]$} & {$[21.83964]$} & {$[18.70140]$} \\
$\mathrm{R}^{2}$ & 0.779383 & \\
Observations & 101 & \\
\hline \multicolumn{2}{l}{ Source: our calculation }
\end{tabular}

The results also show that social justice's coefficient is positive and significant at a $1 \%$ level with R2 equal at $78 \%$. This coefficient displays that more than $6.3 \%$ of the variation in GDP per capita is explained by social justice.

On the whole, the results of the OLS regressions confirm empirically that social justice positively impacts GDP per capita as follows:

\begin{tabular}{lll}
\hline $\mathrm{Y}_{\mathrm{i}}=$ & 4.387269 & $+0.072018 \mathrm{SJ} 3_{\mathrm{i}}$ \\
$($ Std. Error $)$ & $(0.201650)$ & $(24.45739)$ \\
[t-Statistic] & {$[21.75683]$} & {$[24.45739]$} \\
$\mathrm{R}^{2}$ & 0.828294 & \\
Observations & 126 & \\
\hline
\end{tabular}

Source: our calculation

The social justice's coefficient is positive and significant at a 1\% level with R2 strong $83 \%$. This coefficient involves that roughly 7.2\% increase in GDP per capita for only one point in the social justice index, meaning that $7.2 \%$ of the variation in GDP per capita is explained by social justice.

According to equation $\mathrm{Y} 1$, if the countries belong on the class modal, they will be able to increase their social justice as like as Denmark, the regression suggests that GDP per capita can increase to between more than twice and seven times what it was.

\section{Do both education and knowledge improve social justice and/or economic growth?}

Amartya Sen $(1990,2003)$ expanded the theory of human capital via his famous theory of capabilities. The author included education among basic capabilities because it has a power that anyone has to act in his own life. For that, Sen confirmed that capabilities are more important for economic development than the investment in human capital. This author mentioned that "the 
El Alaoui, A. (2019). Education and knowledge are fundamental to social justice and economic growth. International Journal of Social Sciences and Education Research, 5(3), 279-293.

ability to exercise freedom may be directly dependent on the education we have received, and thus the development of the educational sector may have a foundational connection with the capability-based approach," (Sen, 2003, p.55). He confirmed also that "education helps in the intelligent choice between different types of lives that a person can lead," (Sen, 2003, p.55), so education can have important bearings on developing valuable capabilities and thus in the process of human development.

Discussing the approach of capabilities, Lorella Terzi (2004) argues that "the capability to educate can be considered basic, in two ways. First, in that absence or lack of education would essentially harm the individual. Second, since education plays a substantial role in the expansion of other capabilities, as well as future ones, it can be considered a basic capability for the further reason that it is fundamental and foundational to different capabilities," (Lorella Terzi, 2004, p.1).

It's evident that education improves people's knowledge and increases their professional and social status. In its report, UNESCO (2014) declares that education improves people's understanding of politics and how to take part in it. This organization found that "Across $12 \mathrm{Sub}$-Saharan African countries, $63 \%$ of individuals without formal schooling had an understanding of democracy, compared with $71 \%$ of those with primary education and $85 \%$ of those with secondary," (UNESCO, 2014, p.16).

Many studies prove that education has a positive effect on economic growth, but this effect varies according to the conditions, such as quality, fairness and human rights. Using the same data like the below section, we found also that the relationships between the average GDP per capita and both components (the average of access to the basic knowledge and of access to advanced education) are positive and strong, Figure 3 and Figure 4.

Figure 3. Average GDP per capita Vs. Average of access to basic knowledge, during 2014-2017

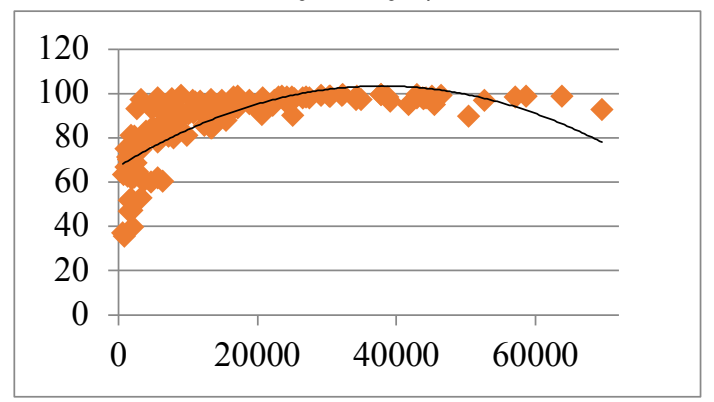

Figure 4. Average GDP per capita Vs. Average of access to advanced education, during 2014-2017

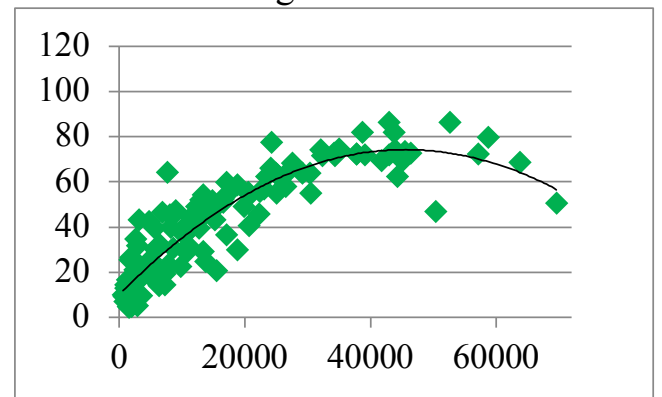

Source: Elaborated according to data of the social progress imperative organization, 2018

We note that the first component (access to basic knowledge) belongs to the dimension of the foundations of well-being and the second one (access to advanced education) belongs to the dimension of opportunity. For more precision, the index of access to basic knowledge was included four indicators, such as the adult literacy rate ( $\%$ of the population, aged $15+)$, the primary school enrolment ( $\%$ of the children), the secondary school enrolment ( $\%$ of the children), and the gender parity in the secondary enrolment. And, the index of access to advanced education contained five indicators, such as years of tertiary schooling, women's average years in school, inequality in the attainment of education, number of globally ranked universities, and percent of tertiary students enrolled in globally ranked universities. 
El Alaoui, A. (2019). Education and knowledge are fundamental to social justice and economic growth. International Journal of Social Sciences and Education Research, 5(3), 279-293.

We can use the OLS regression to measure the impact of the education and the knowledge (as explanatory variables) on GDP per capita as the dependent variable. It is presented as follows:

$$
\mathrm{Y}_{\mathrm{i}}=\varphi_{\mathrm{i}}+\delta_{\mathrm{i}} \mathrm{edu}_{\mathrm{i}}+\eta_{\mathrm{i}} \text { know }_{\mathrm{i}}+\zeta_{\mathrm{i}} \text { Eq.2 }
$$

Where $Y_{i}$ indicates the average of logarithm GDP per capita, $\varphi_{i}$ and $\zeta_{i}$ are the intercept and the term error respectively, $\delta_{\mathrm{i}}$ measures the weight of the advanced education on income, and $\eta_{\mathrm{i}}$ measures the weight of the basic knowledge on income. Table 1 reports the results of all-data, DecileData and QuartData.

Table 1. OLS Regressions of Eq.2

\begin{tabular}{|c|c|c|c|c|}
\hline \multicolumn{2}{|c|}{ Dependent variable } & \multicolumn{3}{|c|}{ Independent variables/ explanatory variables } \\
\hline \multicolumn{2}{|c|}{$\mathrm{Y}_{\mathrm{i}}$} & constant & $\mathrm{edu}_{\mathrm{i}}$ & knowi $_{\text {i }}$ \\
\hline \multirow{5}{*}{ Reg. 21} & Coefficients & 6.060932 & 0.033511 & 0.020393 \\
\hline & (Std. Error) & $(0.336338)$ & $(0.003451)$ & $(0.005109)$ \\
\hline & [t-Statistic $]$ & [18.02033] & [9.710253] & [3.991552] \\
\hline & $\mathrm{R}^{2}$ & 0.810733 & F-statistic & 263.4372 \\
\hline & Observations & 126 & Prob(F-statistic) & 0.000000 \\
\hline \multirow{5}{*}{ Reg.22 } & Coefficients & 6.819159 & 0.031183 & 0.012993 \\
\hline & (Std. Error) & $(0.383396)$ & $(0.003679)$ & $(0.005610)$ \\
\hline & {$[\mathrm{t}-$ Statistic $]$} & {$[17.78620]$} & {$[8.476056]$} & {$[2.316141]$} \\
\hline & $\mathrm{R}^{2}$ & 0.762726 & F-statistic & 157.5127 \\
\hline & Observations & 101 & Prob(F-statistic) & 0.000000 \\
\hline \multirow{5}{*}{ Reg.23 } & Coefficients & 7.425862 & 0.018213 & 0.012851 \\
\hline & (Std. Error) & $(0.586670)$ & $(0.004693)$ & $(0.007844)$ \\
\hline & [t-Statistic] & [12.65764] & [3.880895] & [1.638339] \\
\hline & $\mathrm{R}^{2}$ & 0.495873 & F-statistic & 29.50881 \\
\hline & Observations & 63 & Prob(F-statistic) & 0.000000 \\
\hline
\end{tabular}

Source: Our elaboration

In all models (Reg.21, Reg.22, and Reg.23), the results show that there are positive impacts of the explanatory variables (education and knowledge) on income. All coefficients are significant at the 5\% level except the coefficient of knowledge Reg.23, which it is not significant. We note in Reg. 21 and Reg.22 that more 3\% of the variations of GDP per capita are explained by education, while $1.3 \%$ and $2 \%$ of the variations are explained by knowledge.

According to Reg.23, if the countries, which were belonged to the class modal, they would be able to increase knowledge index to the rating of Canada and education index to the rating of the United States, the regression suggests that GDP could increase to between more than twice and thirteen times what it was.

In the same way, we use the OLS regressions to measure the impact of the education (measured by access to advanced education) and the knowledge (measured by access to basic knowledge) as the explanatory variables on the social progress as the exogenous variable. It is presented as follows:

$$
\mathrm{SJ}_{\mathrm{i}}=\alpha_{\mathrm{i}}+\beta_{\mathrm{i}} \text { edu }_{\mathrm{i}}+\gamma_{\mathrm{i}} \text { know }_{\mathrm{i}}+\varepsilon_{\mathrm{i}} \text { Eq.3 }
$$

Where, $\mathrm{SJ}_{\mathrm{i}}$ indicates the average of social justice index, edu $\mathrm{u}_{\mathrm{i}}$ indicates advanced education, know $w_{\mathrm{i}}$ is basic knowledge, $\alpha_{\mathrm{i}}$ and $\varepsilon_{\mathrm{i}}$ are the intercept and the term error respectively, $\beta_{\mathrm{i}}$ measures the weight of the advanced education on social progress, and $\gamma_{i}$ measures the weight of the basic knowledge on social progress. 
El Alaoui, A. (2019). Education and knowledge are fundamental to social justice and economic growth. International Journal of Social Sciences and Education Research, 5(3), 279-293.

The regressions are applied to all-data (126 observations/countries), QuartData (63 observations) and DecileData (101 observations). The results of the OLS regression show that both education and knowledge are positive impacts on social progress, Table 2.

Table 2. OLS Regressions of Eq.3

\begin{tabular}{|c|c|c|c|c|}
\hline \multicolumn{2}{|c|}{ Dependent variable } & \multicolumn{3}{|c|}{ Independent variables/ explanatory variables } \\
\hline \multicolumn{2}{|c|}{$\mathrm{SJ}_{\mathrm{i}}$} & constant & $\mathrm{edu}_{\mathrm{i}}$ & knowi \\
\hline \multirow{5}{*}{ Reg.31 } & Coefficients & 23.84663 & 0.412665 & 0.301425 \\
\hline & (Std. Error) & $(3.690800)$ & $(0.037871)$ & $(0.056063)$ \\
\hline & [t-Statistic] & [6.461100] & [10.89664] & [5.376548] \\
\hline & $\mathrm{R}^{2}$ & 0.857289 & F-statistic & 369.4401 \\
\hline & Observations & 126 & Prob(F-statistic) & 0.000000 \\
\hline \multirow{5}{*}{ Reg.32 } & Coefficients & 22.89387 & 0.357563 & 0.333506 \\
\hline & (Std. Error) & $(4.931487)$ & $(0.047322)$ & $(0.072155)$ \\
\hline & [t-Statistic] & [4.642386] & {$[7.556005]$} & [4.622102] \\
\hline & $\mathrm{R}^{2}$ & 0.799244 & F-statistic & 195.0769 \\
\hline & Observations & 101 & Prob(F-statistic) & 0.000000 \\
\hline \multirow{5}{*}{ Reg.33 } & Coefficients & 10.83449 & 0.113877 & 0.567055 \\
\hline & (Std. Error) & $(8.285455)$ & $(0.066279)$ & $(0.110782)$ \\
\hline & [t-Statistic] & [1.307652] & [1.718152] & [5.118652] \\
\hline & $\mathrm{R}^{2}$ & 0.604396 & F-statistic & 45.83350 \\
\hline & Observations & 63 & Prob(F-statistic) & 0.000000 \\
\hline
\end{tabular}

Source: Our elaboration

In all models (Reg.31, Reg.32, and Reg.33), the results show also that there are positive impacts of the explanatory variables (advanced education and basic knowledge) in social progress. All coefficients are significant at the $1 \%$ level except the coefficient of education in Reg. 33, which is significant at the $10 \%$ level.

In Reg. 31 and Reg. 32, we found that more than $30 \%$ and $41 \%$ of the variation in social progress is explained by knowledge and education. However, the coefficients don't keep the same weight if we move countries that have the lowest and highest income. The coefficients of education are superior to those of knowledge, implying that $36 \%$ and $41 \%$ of the variation in social progress is explained by access to advanced education since only $30 \%$ and $33 \%$ of this variation is explained by access to basic knowledge. On the other hand, Reg. 33 shows that $57 \%$ of the variation in social progress is explained by access to basic knowledge, while only $11.4 \%$ of this variation is explained by access to advanced education.

\section{Concluding remarks}

In this paper, we find that education has a stronger impact on income than that of knowledge, but its impact is feeble in social progress comparatively to impact of knowledge. Our results also suggest that over $70 \%$ of the variation in GDP per capita is explained by education and knowledge, and over $5 \%$ of the variation in social progress is explained by education and knowledge.

Education is not just like offering another service or activity. It is the best way to improve knowledge, skills, and capabilities. It is the way to 'establish' a free and fair society. However, the questions are how can we give the same education for all? How can we have the same access to education? 
El Alaoui, A. (2019). Education and knowledge are fundamental to social justice and economic growth. International Journal of Social Sciences and Education Research, 5(3), 279-293.

The technology is beginning to change our habits, manners to live and our social relationships. We can communicate faster and easier in spite of our culture and country/region. The challenge is in what how establishes social justice in the world in which everyone can have at least his/her basic needs especially in education, health and security?

\section{References}

El Alaoui, A. (2016). "Impact of Women's Education on the Economic Growth: An Empirical Analysis Applied to Morocco, Algeria, Tunisia, and Egypt". International Journal of Social Sciences and Education Research, 2(3), 1187-1210.

Hayek, F. A. (1976). The mirage of social justice. Chicago: The University of Chicago Press.

Jandhyala B. G. Tilak., (1989). "Education and its relation to economic growth, poverty, and income distribution: past evidence and further analysis". World Bank discussion papers; no. WDP 46. Washington, DC: The World Bank. http://documents.worldbank.org/curated/en /357751468739481512/Educationand-its-relation-to-economic-growth-poverty-and-income-distribution-past-evidence-and-further-analysis

Kelso, O. \& Adler, M., (1958). The capitalist manifesto. New York: Random House. 279 pages http://www.kelsoinstitute.org/pdf/cm-entire.pdf

Mead, L. (1986). Beyond entitlement: The social obligations of citizenship. New York: The Free Press.

Mill. J. S. (1971). Utilitarianism. Indianapolis, IN: Bobbs-Merrill.

Moyes, Patrick (2011). "Utilitarianism or Welfarism: Does it Make a Difference?”. Cahiers du GREThA (Groupe de Recherche en Economie Théorique et Appliquée), n 2011-30.

Nozick, R. (1974). Anarchy, state, and utopia. New York: Basic Books.

Reisch, M. (2002). "Defining social justice in a socially unjust world", Families in Society, 83(4), pp. 343354.

Salmani, D. (2011). "Impacts of social justice perception on Elite Migration“, Iranion journal of reanagement studies, vol - 4, No.1 ( tahran : 2011), p.1.

Sen A. (2003), "Development as Capability Expansion". In: Fukuda-Parr S, et al Readings in Human Development. New Delhi and New York: Oxford University Press.

Sen, A. (1990, June 14). Individual freedom as a social commitment. New York Review of Books, 49-54.

Srivastava,A.K. and Sharma, S., (2017). "Social Justice Through Aadhaar: An e-Policy Initiative", Chapter 5 of book Technology, Society and Sustainability: Selected Concepts, Issues and Cases edited by Lech W. Zacher. pp.83-98.

Sunstein, C. R. (1997). Free markets and social justice. New York: Oxford University Press.

UNESCO, (2012), "Education and skills for inclusive and sustainable development beyond 2015", Thematic Think Piece. Pp.1-16

UNISCO, (2014). "TEACHING AND LEARNING: Achieving quality for all", Education for All Global Monitoring Report, 201 3/4, 496 pages. ISBN 978-92-3-104255-3. www.unesco.org/publishing

Zajda, Joseph (2010). Globalization, Education and Social Justice. Globalisation, Comparative Education and Policy Research 10. Ed. Springer.

\section{Appendices}

Table A.1. Ranking countries, according to average SPI 
El Alaoui, A. (2019). Education and knowledge are fundamental to social justice and economic growth. International Journal of Social Sciences and Education Research, 5(3), 279-293.

\begin{tabular}{|c|c|c|c|c|c|c|c|c|c|c|c|c|c|c|c|}
\hline \multirow{2}{*}{$\begin{array}{l}\text { Countries } \\
\text { Denmark }\end{array}$} & \multirow{2}{*}{$\begin{array}{l}\text { Code } \\
\text { DNK }\end{array}$} & \multicolumn{2}{|c|}{$\begin{array}{l}\text { GDP per cap- } \\
\text { ita }\end{array}$} & \multicolumn{2}{|c|}{ SPI } & \multicolumn{2}{|c|}{ BHN } & \multicolumn{2}{|c|}{ FW } & \multicolumn{2}{|c|}{ Opp } & \multicolumn{2}{|c|}{ Know } & Edı & \\
\hline & & 45131,01 & 9 & 90,24 & 1 & 96,52 & 1 & 90,46 & 5 & 83,74 & 7 & 98,65 & 16 & 69,17 & 21 \\
\hline Finland & FIN & 39091,87 & 16 & 90,12 & 2 & 96,00 & 3 & 88,90 & 11 & 85,47 & 4 & 96,46 & 45 & 71,88 & 17 \\
\hline Iceland & ISL & 42925,08 & 14 & 90,11 & 3 & 95,16 & 7 & 89,38 & 9 & 85,79 & 2 & 98,13 & 25 & 71,98 & 16 \\
\hline Canada & CAN & 42978,05 & 13 & 89,97 & 4 & 95,09 & 8 & 86,44 & 20 & 88,38 & 1 & 99,68 & 1 & 86,36 & 2 \\
\hline Switzerland & $\mathrm{CHE}$ & 57107,31 & 4 & 89,83 & 5 & 96,06 & 2 & 91,34 & 1 & 82,10 & 13 & 98,27 & 23 & 72,36 & 15 \\
\hline Netherlands & NLD & 46454,88 & 7 & 89,80 & 6 & 95,05 & 9 & 91,02 & 2 & 83,34 & 9 & 99,22 & 7 & 72,82 & 12 \\
\hline Sweden & SWE & 45503,49 & 8 & 89,78 & 7 & 95,37 & 6 & 90,57 & 4 & 83,41 & 8 & 95,06 & 53 & 73,23 & 10 \\
\hline Norway & NOR & 63819,19 & 2 & 89,67 & 8 & 94,99 & 10 & 90,88 & 3 & 83,13 & 10 & 98,80 & 14 & 68,71 & 22 \\
\hline Australia & AUS & 43818,26 & 12 & 89,44 & 9 & 94,33 & 13 & 88,65 & 13 & 85,34 & 5 & 97,99 & 29 & 81,97 & 4 \\
\hline New Zealand & NZL & 34961,92 & 20 & 88,98 & 10 & 93,56 & 15 & 88,35 & 14 & 85,03 & 6 & 97,36 & 36 & 74,43 & 7 \\
\hline Ireland & IRL & 58710,51 & 3 & 88,94 & 11 & 93,28 & 18 & 87,83 & 16 & 85,71 & 3 & 98,90 & 12 & 79,51 & 5 \\
\hline United Kingdom & GBR & 38709,95 & 17 & 88,56 & 12 & 92,97 & 19 & 90,05 & 7 & 82,67 & 11 & 98,43 & 19 & 82,00 & 3 \\
\hline Germany & DEU & 43886,73 & 11 & 88,21 & 13 & 94,41 & 12 & 89,59 & 8 & 80,64 & 14 & 97,52 & 33 & 73,98 & 9 \\
\hline Austria & AUT & 44257,95 & 10 & 87,69 & 14 & 95,64 & 5 & 89,27 & 10 & 78,14 & 16 & 98,00 & 28 & 62,40 & 32 \\
\hline Belgium & BEL & 41747,93 & 15 & 86,88 & 15 & 93,97 & 14 & 87,12 & 17 & 79,55 & 15 & 95,02 & 54 & 69,26 & 20 \\
\hline Spain & ESP & 32290,93 & 23 & 86,46 & 16 & 92,24 & 22 & 90,30 & 6 & 76,85 & 17 & 99,46 & 4 & 71,59 & 19 \\
\hline United States & USA & 52700,84 & 5 & 86,29 & 17 & 92,92 & 20 & 83,80 & 29 & 82,15 & 12 & 97,14 & 38 & 86,50 & 1 \\
\hline France & FRA & 37782,76 & 19 & 85,69 & 18 & 92,48 & 21 & 88,71 & 12 & 75,89 & 18 & 99,61 & 3 & 72,44 & 13 \\
\hline Japan & JPN & 37816,31 & 18 & 85,60 & 19 & 95,77 & 4 & 87,11 & 18 & 73,90 & 21 & 99,65 & 2 & 72,40 & 14 \\
\hline Portugal & PRT & 26562,60 & 30 & 85,09 & 20 & 93,29 & 17 & 86,41 & 21 & 75,57 & 20 & 98,09 & 26 & 57,76 & 35 \\
\hline Slovenia & SVN & 29121,32 & 27 & 83,85 & 21 & 93,49 & 16 & 85,67 & 22 & 72,40 & 23 & 99,31 & 5 & 63,63 & 29 \\
\hline Czech Republic & $\mathrm{CZE}$ & 30364,71 & 26 & 83,49 & 22 & 94,47 & 11 & 84,54 & 27 & 71,45 & 25 & 98,74 & 15 & 63,75 & 27 \\
\hline Estonia & EST & 27525,83 & 28 & 82,72 & 23 & 91,23 & 24 & 84,62 & 26 & 72,32 & 24 & 98,01 & 27 & 68,36 & 23 \\
\hline Italy & ITA & 34299,67 & 21 & 82,36 & 24 & 89,09 & 33 & 88,10 & 15 & 69,89 & 27 & 99,01 & 9 & 71,70 & 18 \\
\hline Chile & CHL & 22416,70 & 38 & 82,18 & 25 & 88,22 & 35 & 84,70 & 24 & 73,61 & 22 & 97,10 & 40 & 55,77 & 37 \\
\hline Korea, Rep. & KOR & 34244,05 & 22 & 81,62 & 26 & 91,72 & 23 & 83,43 & 30 & 69,71 & 28 & 97,25 & 37 & 72,84 & 11 \\
\hline Costa Rica & CRI & 14838,69 & 54 & 80,78 & 27 & 87,51 & 37 & 84,10 & 28 & 70,74 & 26 & 96,84 & 42 & 51,58 & 46 \\
\hline Israel & ISR & 32095,41 & 24 & 80,59 & 28 & 90,70 & 27 & 86,55 & 19 & 64,53 & 33 & 99,04 & 8 & 74,09 & 8 \\
\hline Cyprus & CYP & 30473,30 & 25 & 79,99 & 29 & 90,74 & 26 & 84,65 & 25 & 64,58 & 32 & 98,86 & 13 & 55,10 & 40 \\
\hline Poland & POL & 25255,26 & 31 & 79,86 & 30 & 90,11 & 29 & 81,49 & 32 & 68,00 & 29 & 97,53 & 32 & 62,94 & 30 \\
\hline Uruguay & URY & 19914,48 & 43 & 79,74 & 31 & 87,40 & 38 & 76,03 & 51 & 75,80 & 19 & 93,03 & 63 & 48,94 & 51 \\
\hline Greece & GRC & 24156,13 & 35 & 78,71 & 32 & 89,72 & 31 & 85,31 & 23 & 61,11 & 39 & 96,09 & 46 & 65,97 & 24 \\
\hline Hungary & HUN & 24920,18 & 33 & 78,00 & 33 & 90,50 & 28 & 79,76 & 36 & 63,72 & 36 & 98,36 & 21 & 63,69 & 28 \\
\hline Latvia & LVA & 23012,09 & 37 & 77,66 & 34 & 88,39 & 34 & 81,80 & 31 & 62,78 & 37 & 98,58 & 18 & 56,84 & 36 \\
\hline Lithuania & LTU & 26983,32 & 29 & 77,62 & 35 & 87,35 & 39 & 77,95 & 43 & 67,55 & 30 & 98,41 & 20 & 64,91 & 25 \\
\hline Croatia & HRV & 20776,55 & 40 & 77,01 & 36 & 91,20 & 25 & 80,41 & 35 & 59,40 & 43 & 97,90 & 30 & 54,14 & 42 \\
\hline Argentina & $\mathrm{ARG}$ & 18878,57 & 45 & 75,91 & 37 & 82,51 & 53 & 78,85 & 38 & 66,39 & 31 & 97,11 & 39 & 58,61 & 34 \\
\hline Mauritius & MUS & 18887,87 & 44 & 75,04 & 38 & 89,38 & 32 & 75,12 & 56 & 60,62 & 41 & 95,36 & 50 & 29,92 & 81 \\
\hline Panama & PAN & 20691,52 & 41 & 74,01 & 39 & 81,91 & 56 & 80,54 & 34 & 59,57 & 42 & 90,40 & 75 & 40,45 & 67 \\
\hline Kuwait & KWT & 69569,24 & 1 & 73,60 & 40 & $\mathbf{8 9 , 7 7}$ & 30 & 78,08 & 42 & 52,93 & 57 & 92,96 & 64 & 50,49 & 48 \\
\hline Bulgaria & BGR & 17024,18 & 48 & 73,45 & 41 & 87,30 & 40 & 76,15 & 49 & 56,90 & 49 & 96,51 & 44 & 53,87 & 43 \\
\hline Brazil & BRA & 14628,93 & 55 & 73,19 & 42 & 76,81 & 70 & 78,80 & 39 & 63,96 & 35 & 93,80 & 58 & 46,49 & 55 \\
\hline Romania & ROU & 20575,98 & 42 & 72,97 & 43 & 83,28 & 51 & 76,67 & 47 & 58,96 & 44 & 95,18 & 52 & 55,19 & 38 \\
\hline Serbia & SRB & 13347,77 & 60 & 72,11 & 44 & 87,27 & 41 & 73,96 & 62 & 55,10 & 52 & 97,41 & 35 & 54,26 & 41 \\
\hline Jamaica & JAM & 8164,78 & 76 & 71,92 & 45 & 74,57 & 76 & 78,49 & 41 & 62,69 & 38 & 88,10 & 79 & 39,80 & 68 \\
\hline Colombia & $\mathrm{COL}$ & 12953,42 & 61 & 71,58 & 46 & 75,13 & 75 & 78,86 & 37 & 60,75 & 40 & 92,96 & 65 & 52,08 & 45 \\
\hline Peru & PER & 11788,13 & 64 & 71,34 & 47 & 75,22 & 74 & 80,93 & 33 & 57,88 & 47 & 96,71 & 43 & 41,73 & 65 \\
\hline Malaysia & MYS & 25044,28 & 32 & 71,17 & 48 & 87,96 & 36 & 75,12 & 55 & 50,44 & 62 & 90,33 & 76 & 55,11 & 39 \\
\hline Mexico & MEX & 16613,55 & 49 & 71,12 & 49 & 78,49 & 66 & 76,71 & 45 & 58,16 & 46 & 93,35 & 60 & 52,54 & 44 \\
\hline Albania & ALB & 11011,59 & 67 & 70,27 & 50 & 85,33 & 48 & 77,77 & 44 & 47,72 & 74 & 96,02 & 47 & 31,84 & 77 \\
\hline Montenegro & MNE & 15266,26 & 53 & 70,02 & 51 & 84,45 & 50 & 75,24 & 54 & 50,39 & 63 & 95,60 & 48 & 42,97 & 63 \\
\hline Ecuador & ECU & 10712,95 & 69 & 69,87 & 52 & 78,01 & 69 & 78,67 & 40 & 52,94 & 56 & 96,85 & 41 & 37,15 & 72 \\
\hline Georgia & GEO & 9016,76 & 73 & 69,76 & 53 & 86,01 & 44 & 73,45 & 64 & 49,82 & 67 & 99,28 & 6 & 47,30 & 52 \\
\hline Tunisia & TUN & 10755,83 & 68 & 69,41 & 54 & 83,07 & 52 & 75,99 & 52 & 49,17 & 69 & 91,37 & 72 & 28,80 & 83 \\
\hline Macedonia, FYR & MKD & 12711,22 & 62 & 69,40 & 55 & 86,68 & 43 & 72,63 & 69 & 48,90 & 70 & 88,93 & 78 & 39,33 & 70 \\
\hline Jordan & JOR & 8935,71 & 74 & 69,26 & 56 & 84,89 & 49 & 74,28 & 60 & 48,60 & 72 & 91,92 & 70 & 46,14 & 56 \\
\hline Saudi Arabia & SAU & 50356,08 & 6 & 68,69 & 57 & 85,87 & 45 & 75,83 & 53 & 44,39 & 88 & 89,74 & 77 & 46,87 & 53 \\
\hline Turkey & TUR & 22251,71 & 39 & 68,65 & 58 & 85,47 & 46 & 74,46 & 59 & 46,02 & 81 & 94,86 & 55 & 45,66 & 57 \\
\hline Paraguay & PRY & 8662,80 & 75 & 68,63 & 59 & 78,11 & 68 & 72,86 & 67 & 54,92 & 53 & 87,64 & 81 & 30,60 & 79 \\
\hline Thailand & THA & 15280,05 & 52 & 68,28 & 60 & 80,75 & 61 & 73,86 & 63 & 50,23 & 64 & 94,25 & 57 & 49,57 & 49 \\
\hline Ukraine & UKR & 7708,37 & 80 & 68,14 & 61 & 81,26 & 59 & 67,50 & 85 & 55,66 & 51 & 97,67 & 31 & 64,05 & 26 \\
\hline Armenia & ARM & 8066,07 & 77 & 68,11 & 62 & 85,36 & 47 & 74,82 & 57 & 44,15 & 89 & 92,73 & 67 & 45,36 & 59 \\
\hline Belarus & BLR & 17144,51 & 46 & 67,83 & 63 & 87,17 & 42 & 68,65 & 78 & 47,67 & 75 & 98,98 & 11 & 59,78 & 33 \\
\hline Dominican Rep. & DOM & 13370,37 & 59 & 67,79 & 64 & 72,32 & 80 & 76,71 & 46 & 54,33 & 55 & 84,44 & 86 & 29,15 & 82 \\
\hline El Salvador & SLV & 7909,56 & 78 & 67,14 & 65 & 72,26 & 81 & 76,34 & 48 & 52,81 & 58 & 92,60 & 68 & 22,90 & 91 \\
\hline Philippines & PHL & 6908,74 & 83 & 66,70 & 66 & 71,13 & 83 & 71,13 & 72 & 57,84 & 48 & 92,58 & 69 & 46,59 & 54 \\
\hline
\end{tabular}


El Alaoui, A. (2019). Education and knowledge are fundamental to social justice and economic growth. International Journal of Social Sciences and Education Research, 5(3), 279-293.

\begin{tabular}{|c|c|c|c|c|c|c|c|c|c|c|c|c|c|c|c|}
\hline South Africa & $\mathrm{ZAF}$ & 12385,13 & 63 & 66,61 & 67 & 66,73 & 88 & 68,80 & 77 & 64,30 & 34 & 85,49 & 82 & 48,95 & 50 \\
\hline Russian Federation & RUS & 24231,35 & 34 & 66,51 & 68 & 78,92 & 64 & 71,44 & 71 & 49,17 & 68 & 98,62 & 17 & 77,49 & 6 \\
\hline Moldova & MDA & 4798,98 & 92 & 66,26 & 69 & 79,25 & 63 & 69,59 & 75 & 49,93 & 65 & 93,28 & 61 & 42,29 & 64 \\
\hline Bolivia & BOL & 6523,83 & 84 & 65,97 & 70 & 73,09 & 77 & 72,83 & 68 & 51,98 & 61 & 90,92 & 73 & 32,01 & 76 \\
\hline Lebanon & LBN & 13385,24 & 58 & 65,94 & 71 & 76,01 & 73 & 74,81 & 58 & 47,00 & 78 & 84,63 & 85 & 45,38 & 58 \\
\hline Kazakhstan & KAZ & 23518,36 & 36 & 65,50 & 72 & 81,05 & 60 & 65,59 & 89 & 49,85 & 66 & 98,98 & 10 & 62,45 & 31 \\
\hline Algeria & DZA & 13738,06 & 56 & 65,09 & 73 & 78,76 & 65 & 76,14 & 50 & 40,38 & 100 & 92,76 & 66 & 24,74 & 88 \\
\hline Azerbaijan & AZE & 16526,74 & 50 & 65,04 & 74 & 81,83 & 57 & 72,88 & 66 & 40,41 & 99 & 98,30 & 22 & 50,95 & 47 \\
\hline Sri Lanka & LKA & 11044,37 & 66 & 64,83 & 75 & 76,29 & 71 & 70,80 & 73 & 47,39 & 77 & 95,19 & 51 & 41,53 & 66 \\
\hline Nicaragua & $\mathrm{NIC}$ & 4941,65 & 91 & 64,75 & 76 & 72,73 & 79 & 74,12 & 61 & 47,40 & 76 & 84,84 & 84 & 25,26 & 87 \\
\hline Morocco & MAR & 7246,81 & 82 & 64,41 & 77 & 78,32 & 67 & 73,02 & 65 & 41,89 & 94 & 81,08 & 91 & 19,21 & 99 \\
\hline Indonesia & IDN & 10380,08 & 70 & 63,99 & 78 & 72,89 & 78 & 70,35 & 74 & 48,70 & 71 & 91,76 & 71 & 36,50 & 74 \\
\hline Kyrgyz Republic & KGZ & 3234,05 & 99 & 63,98 & 79 & 76,19 & 72 & 67,74 & 82 & 48,02 & 73 & 97,51 & 34 & 43,22 & 62 \\
\hline Botswana & BWA & 15467,59 & 51 & 63,94 & 80 & 69,52 & 85 & 65,62 & 88 & 56,68 & 50 & 87,82 & 80 & 20,45 & 97 \\
\hline China & CHN & 13575,00 & 57 & 63,05 & 81 & 79,28 & 62 & 67,53 & 84 & 42,36 & 91 & 95,52 & 49 & 45,20 & 60 \\
\hline Guatemala & GTM & 7264,98 & 81 & 62,85 & 82 & 71,71 & 82 & 71,91 & 70 & 44,93 & 84 & 80,84 & 93 & 14,24 & 106 \\
\hline Egypt, Arab Rep. & EGY & 10136,17 & 71 & 62,53 & 83 & 81,48 & 58 & 68,40 & 81 & 37,70 & 108 & 90,91 & 74 & 37,60 & 71 \\
\hline Mongolia & $\mathrm{MNG}$ & 11399,90 & 65 & 61,52 & 84 & 66,26 & 89 & 60,01 & 97 & 58,28 & 45 & 94,75 & 56 & 44,29 & 61 \\
\hline Namibia & NAM & 9802,91 & 72 & 61,42 & 85 & 61,25 & 95 & 68,57 & 79 & 54,45 & 54 & 81,04 & 92 & 22,55 & 93 \\
\hline Uzbekistan & UZB & 5706,49 & 87 & 61,36 & 86 & 82,22 & 54 & 60,16 & 96 & 41,68 & 96 & 98,14 & 24 & 39,40 & 69 \\
\hline Iran Islamic Rep. & IRN & 17107,44 & 47 & 60,76 & 87 & 82,12 & 55 & 66,91 & 87 & 33,27 & 118 & 93,75 & 59 & 36,58 & 73 \\
\hline Honduras & HND & 4429,94 & 94 & 60,59 & 88 & 66,98 & 87 & 69,38 & 76 & 45,39 & 83 & 82,36 & 89 & 21,96 & 94 \\
\hline Ghana & GHA & 3933,37 & 95 & 60,20 & 89 & 59,88 & 97 & 68,41 & 80 & 52,29 & 60 & 83,01 & 88 & 21,41 & 95 \\
\hline Tajikistan & TJK & 2652,67 & 105 & 58,52 & 90 & 69,94 & 84 & 67,46 & 86 & 38,15 & 107 & 93,12 & 62 & 34,78 & 75 \\
\hline Nepal & NPL & 2297,53 & 107 & 58,07 & 91 & 68,60 & 86 & 63,16 & 90 & 42,45 & 90 & 80,70 & 94 & 8,95 & 115 \\
\hline India & IND & 5741,65 & 86 & 57,08 & 92 & 64,78 & 92 & 60,00 & 98 & 46,48 & 80 & 85,28 & 83 & 30,35 & 80 \\
\hline Senegal & SEN & 2291,46 & 108 & 57,01 & 93 & 64,14 & 93 & 60,32 & 95 & 46,57 & 79 & 62,30 & 113 & 7,40 & 118 \\
\hline Kenya & KEN & 2853,82 & 102 & 55,39 & 94 & 53,01 & 106 & 67,71 & 83 & 45,45 & 82 & 78,77 & 96 & 31,53 & 78 \\
\hline Cambodia & KHM & 3289,60 & 97 & 53,72 & 95 & 60,20 & 96 & 61,94 & 92 & 39,03 & 103 & 74,73 & 102 & 16,80 & 101 \\
\hline Bangladesh & BGD & 3140,49 & 101 & 53,13 & 96 & 65,51 & 90 & 59,50 & 101 & 34,38 & 116 & 77,69 & 98 & 17,71 & 100 \\
\hline Myanmar & MMR & 5015,73 & 90 & 52,95 & 97 & 65,47 & 91 & 56,48 & 106 & 36,91 & 111 & 84,22 & 87 & 25,59 & 85 \\
\hline Malawi & MWI & 1093,72 & 123 & 52,39 & 98 & 55,04 & 102 & 57,74 & 103 & 44,40 & 87 & 75,03 & 101 & 14,18 & 107 \\
\hline Rwanda & RWA & 1690,04 & 114 & 52,32 & 99 & 57,30 & 98 & 59,53 & 100 & 40,12 & 101 & 75,89 & 100 & 15,67 & 105 \\
\hline Swaziland & SWZ & 7868,78 & 79 & 51,62 & 100 & 56,62 & 99 & 53,68 & 116 & 44,56 & 86 & 79,90 & 95 & 23,14 & 90 \\
\hline Benin & BEN & 1982,56 & 110 & 51,48 & 101 & 53,26 & 105 & 56,46 & 107 & 44,74 & 85 & 61,59 & 115 & 7,65 & 117 \\
\hline Lesotho & LSO & 2722,93 & 104 & 51,20 & 102 & 51,21 & 110 & 50,06 & 121 & 52,32 & 59 & 64,54 & 108 & 24,39 & 89 \\
\hline Pakistan & PAK & 4708,14 & 93 & 50,00 & 103 & 63,68 & 94 & 53,39 & 117 & 32,92 & 119 & 60,12 & 118 & 19,48 & 98 \\
\hline Tanzania & TZA & 2496,58 & 106 & 49,89 & 104 & 47,28 & 115 & 60,47 & 94 & 41,93 & 93 & 68,91 & 106 & 21,07 & 96 \\
\hline Uganda & UGA & 1682,08 & 115 & 49,48 & 105 & 51,68 & 108 & 57,26 & 105 & 39,51 & 102 & 69,57 & 105 & 25,50 & 86 \\
\hline Cote d'Ivoire & CIV & 3255,23 & 98 & 49,48 & 106 & 53,48 & 104 & 56,38 & 108 & 38,59 & 105 & 52,89 & 119 & 9,17 & 114 \\
\hline Burkina Faso & BFA & 1603,46 & 117 & 49,16 & 107 & 51,19 & 111 & 54,28 & 113 & 42,00 & 92 & 51,95 & 121 & 6,61 & 122 \\
\hline Mauritania & MRT & 3630,82 & 96 & 49,02 & 108 & 55,82 & 100 & 57,72 & 104 & 33,50 & 117 & 60,44 & 117 & 9,40 & 112 \\
\hline Congo, Rep. & $\mathrm{COG}$ & 5593,84 & 89 & 48,96 & 109 & 46,52 & 118 & 62,98 & 91 & 37,37 & 109 & 77,95 & 97 & 22,76 & 92 \\
\hline Zimbabwe & ZWE & 1848,76 & 112 & 48,68 & 110 & 49,58 & 112 & 59,63 & 99 & 36,84 & 112 & 81,19 & 90 & 26,47 & 84 \\
\hline Liberia & LBR & 782,13 & 125 & 48,33 & 111 & 46,04 & 119 & 58,18 & 102 & 40,77 & 97 & 63,37 & 111 & 9,36 & 113 \\
\hline Cameroon & CMR & 3189,56 & 100 & 48,18 & 112 & 52,81 & 107 & 54,80 & 111 & 36,92 & 110 & 77,40 & 99 & 16,77 & 102 \\
\hline Mozambique & $\mathrm{MOZ}$ & 1111,58 & 122 & 48,11 & 113 & 46,54 & 117 & 55,99 & 110 & 41,78 & 95 & 66,98 & 107 & 12,73 & 109 \\
\hline Mali & MLI & 1915,12 & 111 & 48,05 & 114 & 55,26 & 101 & 53,79 & 115 & 35,12 & 114 & 47,20 & 122 & 6,68 & 120 \\
\hline Nigeria & NGA & 5604,07 & 88 & 47,81 & 115 & 46,85 & 116 & 61,57 & 93 & 35,00 & 115 & 61,89 & 114 & 16,54 & 104 \\
\hline Togo & TGO & 1354,71 & 121 & 47,05 & 116 & 48,36 & 113 & 54,50 & 112 & 38,30 & 106 & 62,64 & 112 & 11,37 & 110 \\
\hline Madagascar & MDG & 1380,46 & 120 & 46,73 & 117 & 45,40 & 121 & 54,28 & 114 & 40,50 & 98 & 71,28 & 103 & 16,56 & 103 \\
\hline Sierra Leone & SLE & 1462,72 & 119 & 45,65 & 118 & 42,18 & 123 & 56,04 & 109 & 38,75 & 104 & 70,13 & 104 & 4,65 & 125 \\
\hline Ethiopia & ETH & 1523,98 & 118 & 44,16 & 119 & 51,25 & 109 & 52,63 & 118 & 28,60 & 122 & 63,71 & 109 & 7,79 & 116 \\
\hline Yemen, Rep. & YEM & 2845,48 & 103 & 43,79 & 120 & 55,02 & 103 & 51,25 & 119 & 25,12 & 124 & 63,60 & 110 & 5,19 & 123 \\
\hline Niger & NER & 905,05 & 124 & 42,75 & 121 & 47,60 & 114 & 44,66 & 123 & 35,99 & 113 & 35,65 & 126 & 6,93 & 119 \\
\hline Guinea & GIN & 1611,53 & 116 & 42,50 & 122 & 45,63 & 120 & 51,05 & 120 & 30,79 & 120 & 46,93 & 123 & 4,39 & 126 \\
\hline Angola & $\mathrm{AGO}$ & 6353,46 & 85 & 40,65 & 123 & 44,34 & 122 & 48,77 & 122 & 28,86 & 121 & 60,57 & 116 & 13,81 & 108 \\
\hline Chad & TCD & 2003,55 & 109 & 35,03 & 124 & 35,53 & 125 & 44,11 & 124 & 25,45 & 123 & 39,83 & 124 & 4,81 & 124 \\
\hline Afghanistan & AFG & 1768,99 & 113 & 34,60 & 125 & 41,99 & 124 & 36,79 & 125 & 25,02 & 125 & 52,69 & 120 & 6,64 & 121 \\
\hline Cent. African Rep. & CAF & 614,27 & 126 & 29,43 & 126 & 29,60 & 126 & 35,57 & 126 & 23,11 & 126 & 37,03 & 125 & 9,94 & 111 \\
\hline
\end{tabular}

Note:

$\boldsymbol{S P I}$ is the social progress Index, $\boldsymbol{B H} \boldsymbol{N}$ is the basic human needs; $\boldsymbol{F} \boldsymbol{W}$ is the foundation of well-being; $\boldsymbol{u p}$ is the opportunity; Know is the access to basic knowledge, and $\boldsymbol{E} \boldsymbol{d} \boldsymbol{u}$ is the access to advanced education. 
El Alaoui, A. (2019). Education and knowledge are fundamental to social justice and economic growth. International Journal of Social Sciences and Education Research, 5(3), 279-293.

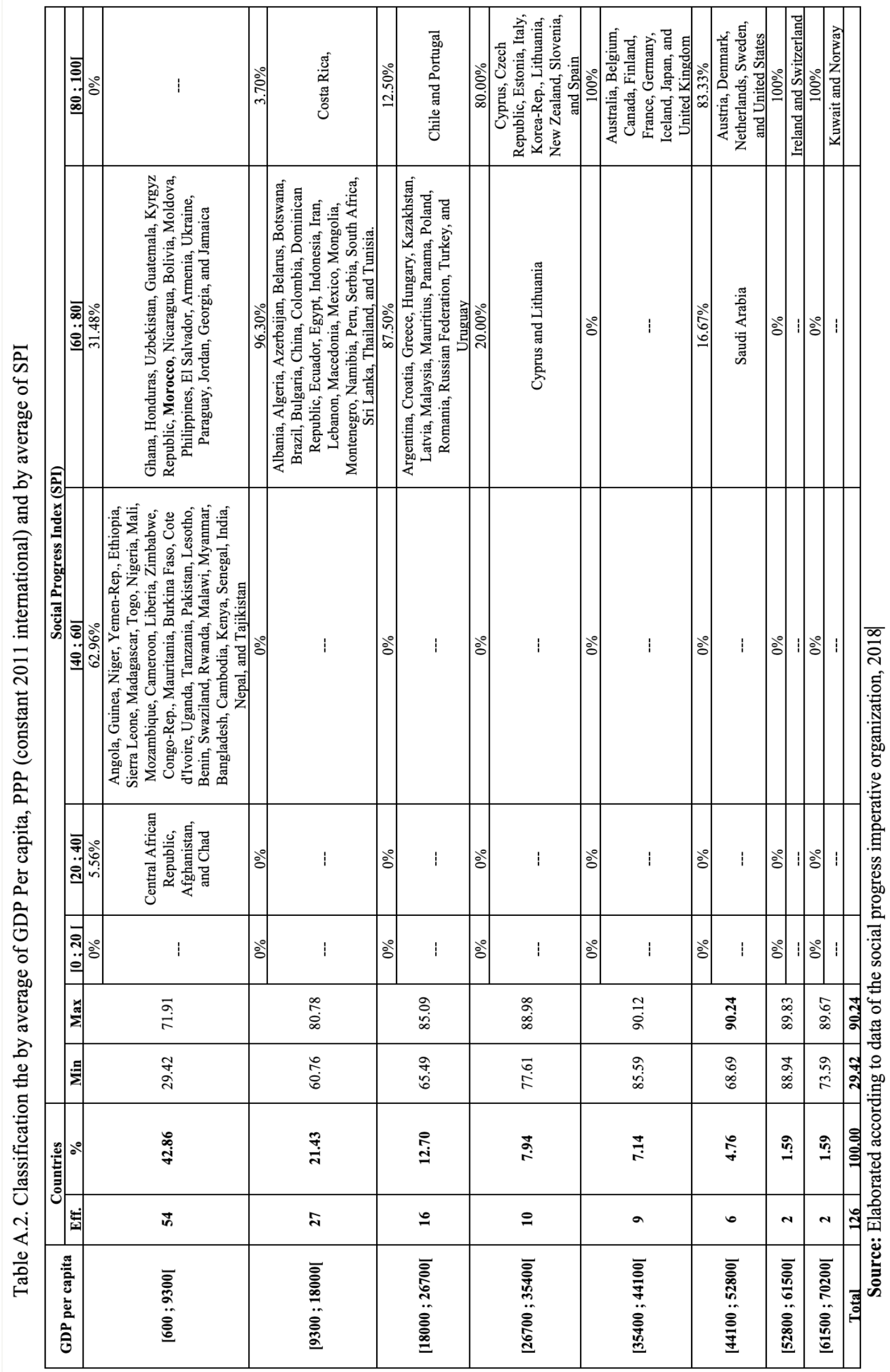

